\title{
Dampak Kebiasaan Begadang Terhadap \\ Pola Tidur Dan Kesehatan
}

\author{
Danang Fahturosi \\ IIK STRADA \\ Ryancoper2033@gmail.com
}

\begin{abstract}
Abstrak
Begadang adalah suatu kebiasaan terjaga sampai larut malam dan tidur saat pagi datang. kebanyakan masyarakat mulai melakukan kegiatan begadang karena mengerjakan pekerjaan hingga larut malam, tetapi karena sering dilakukan tanpa disadari kegiatan saat begadang pun sudah menjadi kebiasaan yang buruk yang dapat menimbulkan penyakit.Masih rendahnya tingkat kesadaran masyarakat yang terbiasa terjaga hingga larut malam, hal tersebut menyebabkan buruknya pola tidur yang mereka miliki dan sangat berpengaruh pada kesehatan.Begadang juga mempengaruhi pola tidur, Pola tidur yang buruk mengakibatkan kesehatan fisiologis dan psikologis menurun. Secara fisiologis, pola tidur yang buruk dapat menyebabkan rendahnya tingkat kesehatan individu dan meningkatkan kelelahan atau mudah letih. Secara psikologis, dapat mengakibatkan ketidakstabilan emosional, kurang percaya diri, impulsif yang berlebihan dan kecerobohan.
\end{abstract}

Kata kunci:Begadang kekebalan tubuh ,medis, kesehatan

\section{Latar Belakang}

Begadang adalah kebiasaan terjaga sampai larut malam dan tertidur saat pagi datang. Begadang bagi masyarakat Indonesia sudah menjadi suatu kebiasaan yang umum terjadi, kebanyakan kegiatan begadang diawali karena mengerjakan pekerjaan hingga larut malam. Begadang boleh saja dilakukan, tetapi jika dilakukan secara terus menerus akan berdampak buruk bagi tubuh. Jika sudah menjadi kebiasaan begadang bisa juga berbahaya bagi kesehatan psikis salah satunya menyebabkan sulit konsentrasi. Banyak kecelakaan kendaraan bermotor diakibtakan karena sulit konsentrasi atau mengantuk. Hingga masalah mengantuk sambil berkendara melahirkan aturan yang mewajibkan seluruh pengendara berkonsentrasi, di dalam Undang Undang No 22/2009 tentang Lalu Lintas dan Angkutan Jalan (LLAJ), di pasal 106 ayat (1) Selain berbahaya terhadap psikis, dampak paling besar yang bisa terjadi adalah kematian. Seorang gamer remaja asal Thailand bernama Dej Nam (18) ditemukan meninggal oleh ibunya, Ging, pada Sabtu pekan lalu. Sang bunda mengecek ke kamarnya karena Nam tidak turun ke bawah saat makan siang. 
Ging mengungkapkan bahwa putranya memiliki kebiasaan begadang hingga pagi hari untuk bermain gim di ponsel dan komputernya. untuk memastikan penyebab kematiannya. Tak lama setelah itu, Kapten Polisi Kittisak Kammana mengungkapkan, kemungkinan Nam meninggal karena gagal jantung diakibatkan kurang tidur., minum air putih saat begadang lebih baik dibandingkan minum air yang mengandung kafein atau gula. Selain kopi, makanan dan minuman yang tidak dianjurkan untuk dikonsumsi saat begadang adalah makanan cepat saji karena banyak mengandung zat-zat yang buruk bagi tubuh. Selanjutnya makanan atau minuman dengan kandungan gula yang tinggi dikarenakan dapat menimbulkan penumpukan lemak yang berakibat buruk pada tubuh. Terakhir adalah makan - makanan berat, ketika saat selesai begadang tubuh akan bekerja cukup keras untuk mencerna makanan. Dalam hal ini masyarakat belum mengetahui sepenuhnya akibat kebiasaan begadang.Begadang kebiasaan yang sudah ada sejak dulu, tetapi ada hal yang membedakan zaman sekarang dan dulu. Perbedaanya adalah asupan makanan dan aktifitas yang dilakukan. Saat zaman dahulu orangorang masih banyak yang melakukan aktifitas fisik dan asupan makanan yang masuk masih banyak diolah oleh sendiri. Berbeda dengan sekarang, banyak orang menjadi malas beraktifitas, seperti tidak punya cukup waktu karena bekerja, pengaruh dari sosial media dan game online hingga kurangnya motivasi untuk berolahraga. Selain itu,sekarang makanan yang masuk kedalam tubuh lebih banyak makanan cepat saji. Makanan tersebut memberikan dampak buruk bagi tubuh jika dikonsumsi secara terus-menerus. Dalam hal ini dapat disimpulkan bahwa masyarakat sekarang kurang memperhatikan dan mempersiapkan tubuh agar tidak memperburuk efek begadang pada tubuh.

\section{Kasus/Masalah}

Begadang sudah menjadi suatu kebiasaan yang umum.Upaya menanggulani kebiasaan begadang karena yang dilakukan saat begadang akan memberikan dampak besar bagi tubuh

\section{Tinjauan pustaka}

Dampak Begadang Bagi Tubuh Dan Psikis

Dampak Kebiasaan Begadang Terhadap Pola Tidur Sehat Bagi Remaja

Faktor Yang Mempengaruhi Begadang

\section{Pembahasan}

Menurut Mahendra di dalam buku Tubuh Anda Cerminan Kesehatan Anda (2010, h.74) "Begadang dapat memicu timbulnya berbagai penyakit dan disebabkan oleh rusaknya sistem imun, tubuh juga perlu beristirahat. Apabila tidak beristirahat, organ-organ tidak dapat melakukan fungsinya dengan optimal. Hal ini akan menimbulkan masalah atau penyakit yang dapat menyerang tubuh." Hal ini membuktikan bahwa sebenarnya begadang bukan lah kebiasaan yang bagus jika dipaksakan untuk dilakukan jika tubuh sedang kelelahan.

Sedangkan dampak begadang menurut Handoyo dalam buku Aplikasi Olah Nafas (2005, h.30) "Begadang memang dapat menguras tenaga yang dapat 
membuat tubuh menjadi lemah. Saat lelah tubuh akan lebih terasa lebih mudah cepat pegal dan tubuh ingin cepat cepat beristirahat kembali. Maka dari itu rasa lelah inilah yang akan membuat sulit berkonsentrasi." Dengan kata lain tidak hanya menyerang fisik begadang yang dipaksakan akan menyerang secara psikis.

Tidur merupakan kebutuhan dasar manusia yang mutlak harus dipenuhi oleh semua orang. Setiap orang memerlukan tidur yang cukup untuk dapat melakukan kegiatan secara optimal di kemudian hari.Manfaat dari tidur itu sendiri adalah untuk mengistirahatkan tubuh,sehingga setiap orang pasti membutuhkannya. Tidur memiliki beberapa dampak positif yaitu memperbaiki sel rusak,meningkatkan daya ingat, mencegah penyakit, meningkatkan energi, dan mencegah stress. Oleh karena itu setiap manusia harus mendapatkan hasil istirahat yang maksimal agar mendapatkan kualitas tidur yang baik (American Pillo, 2015).Dampakdampak yang disebabkan dari pola tidur yang tidak teratur antara lain, tidur kurang dari lima jam dalam satu malam, dapat beresiko terjangkit depresi, stress, penyakit jantung, struk dan diabetes. Pada wanita, yang tidur sebanyak 6 jam atau kurang dari jumlah tersebut setiap malam memiliki peluang $62 \%$ lebih besar terkena kanker payudara, dibanding mereka yang tidur sebanyak 7 jam. Kurangnya jam tidur telah terbukti dapat mengakibatkan siklus hormon dan metabolisme menjadi tidak seimbang (Green, 2012)Pola tidur dikategorikan sesuai dengan umur, mulai dari anak-anak dengan usia enam tahun memiliki jam tidur 11 jam yang cukup untuk memenuhi kualitas tidur. Pada usia remaja hampir menyamai tidur dengan dewasa muda dengan rentang usia (16-30 tahun), mereka cenderung memliki pola tidur yang berbeda dibandingkan usia lainnya. Ini disebabkan oleh perubahan hormonal yang terjadi di akhir pubertas, secara umum kebutuhan tidur pada masa ini berkisar 7-8 jam setiap malamnya.

Begadang adalah keadaan seseorang berjaga tidak tidur sampai larut malam. Berbeda dengan insomnia, insomnia adalah masalah kesehatan dimana seseorang mengalami kesulitan untuk tidur, terutama tidur malam hari. Penderita insomnia pun tidak terbatas pada kisaran umur tertentu. Insomnia dapat didefinisikan juga sebagai suatu persepsi seseorang yang terus merasa tidak cukup tidur atau merasakan kualitas tidur yang buruk (Susilo dan Wulandari, 2011).Pola tidur tidak baik yang disebabkan karena terlalu sering begadang dapat berpengaruh terhadap aktivitas sehari hari seperti, menurunkan daya tahan tubuh, produktivitas menurun, kurangnya konsentrasi, serta emosi tidak stabil. Tapi hal tersebut dapat diatasi dengan mengurangi aktivitas malam di luar rumah, kurangi penggunaan gadget minimal 1 jam sebelum tidur, olahraga teratur 3-4 kali dalam seminggu minimal 30 menit, hindari minuman berkafein dan merokok.

Terdapat beberapa faktor yang mempengaruhi kualitas tidur seseorang menurut (AlMaqassary, Ardi, 2014),

yaitu:

1. Lingkungan 
Lingkungan dapat mendukung dan menghambat tidur. Temperatur, ventilasi, penerangan ruangan dan kondisi kebisingan sangat berpengaruh terhadap tidur seseorang.

2. Kelelahan

Kelelahan akan berpengaruh terhadap pola tidur seseorang. Semakin lelah seseorang maka akan semakin kurang kualitas tidurnya.

3. Penyakit

Sakit menyebabkan nyeri dapat menimbulkan masalah tidur. Seseorang yang sedang sakit membutuhkan waktu tidur lebih lama dari keadaan normal. Sering sekali pada orang sakit pola tidurnya juga akan terganggu karena penyakitnya seperti rasa nyeri yang ditimbulkan oleh luka.

4. Gaya hidup

Orang yang bekerja shift dan sering berubah shiftnya harus mengatur kegiatan agar dapat tidur pada waktu yang tepat. Keadaan rileks sebelum istirahat merupakan faktor yang berpengaruh terhadap seseorang untuk dapat tidur.

5. Obat-obatan dan alkohol

Beberapa obat-obatan berpengaruh terhadap kualitas tidur. Obat-obatan yang mengandung diureticmenyebabkan insomnia, anti depresan akan memsupresi kualitas tidur. Orang yang minum alkohol terlalu banyak sering kali mengalami gangguan tidur.

\section{Merokok}

Nicotine mempunyai efek menstimulasi tubuh dan perokok seringkali mempunyai lebih banyak kesulitan untuk bisa tidur dibandingkan dengan yang tidak merokok. Dengan menahan tidak merokok setelah makan malam, orang biasanya akan tidur lebih baik. Banyak perokok melaporkan pola tidurnya menjadi lebih baik ketika mereka berhenti merokok.

\section{Kesimpulan}

Banyaknya faktor eksternal dan kurangnya pemahaman mengenai dampak dari kebiasaan begadang, sehingga masyarakat khususnya remaja masih mengabaikan tentang pentingnya pola tidur sehat. Dalam perancangan Iklan Layanan Masyarakat ini yang harus dilakukan pertama kali adalah menganalisa tentang permasalahan yang ada untuk mencari solusi yang tepat bagi pemecahan masalah tersebut, selain itu perlu juga dilakukan studi pustaka yang membantu proses pencarian pemecahan masalah.Dengan adanya perancangan iklan layanan masyarakat dalam bentuk media infografis ini, diharapkan mampu meningkatkan kesadaran masyarakat khususnya remaja agar lebih peduli terhadap pola tidur sehat. Penulis juga menggunakan media pendukung yang sering ditemui dan biasa digunakan oleh remaja yaitu seperti poster, $\mathrm{x}$ banner, iklan media sosial, stiker, bantal, dan jam dinding. Dengan didukung oleh penentuan media yang tepat dan ditambah strategi penyebaran media yang baik maka remaja di kota Bandung dapat lebih peduli terhadap pola tidur sehat.Saran Banyak hal yang telah penulis alami selama melaksanakan skripsi ini. Adapun beberapa saran untuk membangun kepentingan bersama, yaitu Perlu adanya penyampaian pesan iklan layanan masyarakat yang lebih kreatif dan komunikatif agar menambah minat masyarakat. Pihak pemerintah harus lebih sering melakukan sosialisasi atau penyuluhan untuk meningkatkan 
kesadaran masyarakat mengenai hal-hal kecil yang dapat berdampak buruk bagi kesehatan. Masyarakat harus lebih peduli dalam menjaga kesehatan

\section{Daftar Pustaka}

Nugraha yogis pratama putra.(2017). Perancangan Infografis Tentang Dampak

Kebiasaan Begadang Terhadap Pola Tidur Sehat Bagi Remaja.Jurnal sketsa vol. 4 No 2

Sahida Sakur Saraswati.(2019).Faktor-Faktor Psikologi yang mempengaaruhi kesehtan tidur mahasiswa.UNIVERSITAS UIN SYARIF HADAYATULLAH JAKARTA

Idriansyah, Muta Afif (2020) Konseling Kelompok Dalam Mengatasi Perilaku Begadang Remaja Awal Di Kampung Karanganyar. Diploma atau S1 thesis, UIN SMH BANTEN.

Abdullah Azam, Muhammad (2021) DAMPAK KEDAI KOPI FREE WI-FI TERHADAP POLA HIDUP DAN POLA IBADAH REMAJA (STUDI KASUS DI KEDAI SOR SAWO PONOROGO). Skripsi (S1) thesis, Universitas Muhammadiyah Ponorogo. 